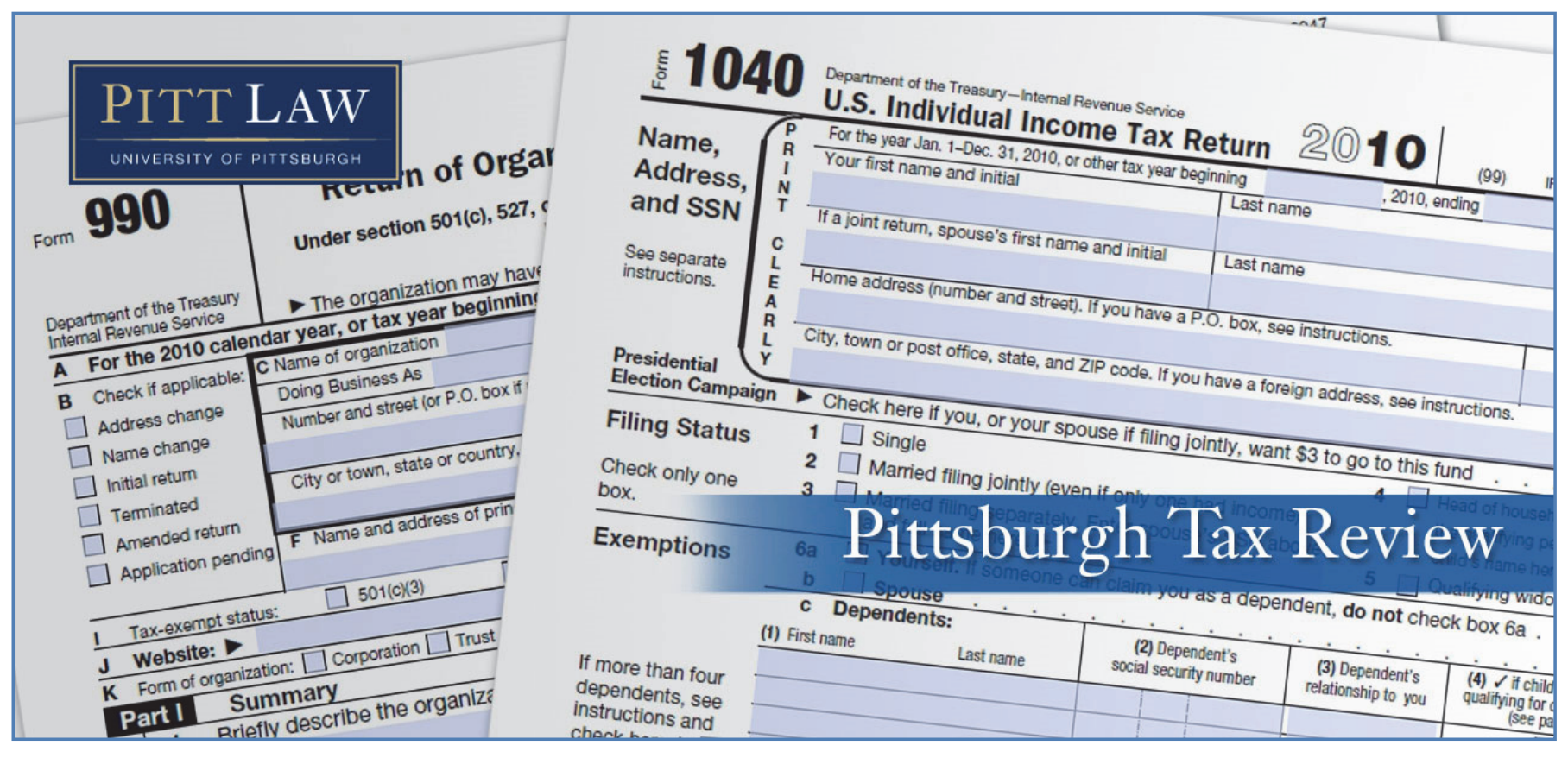

Volume 18 (2020) | ISSN 1932-1821 (print) 1932-1996 (online)

DOI 10.5195/taxreview.2020.118 | http://taxreview.law.pitt.edu

\title{
SHOWING US HOW TO GET IT DONE: NINA OLSON
}

\author{
Caroline D. Ciraolo
}

\section{(cc) BY-NC-ND}

This work is licensed under a Creative Commons Attribution-Noncommercial-No Derivative Works 3.0 United States License.

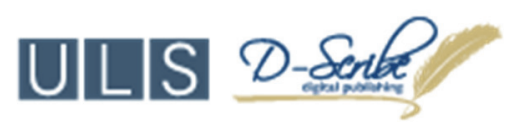

This journal is published by the University Library System of the University of Pittsburgh as part of its D-Scribe Digital Publishing Program, and is cosponsored by the University of Pittsburgh Press. 


\title{
SHOWING US HOW TO GET IT DONE: NINA OLSON
}

\author{
Caroline D. Ciraolo*
}

A Brilliant Mind. A Caring Heart. A Force of Nature. These are just some of the ways we have described our friend, our mentor, our champion: Nina Olson. The former National Taxpayer Advocate and founder of the Center for Taxpayer Rights has been a leader in the tax controversy bar since her days at the Community Tax Law Project, which she formed in 1992. ${ }^{1}$ For nearly thirty years, Nina has worked tirelessly for taxpayers navigating their way through our nation's complex tax system and, along the way, taught legions of tax practitioners, government employees, and elected officials the importance of a fair and efficient tax system for all.

I was and continue to be one of the many private practitioners who have benefited from Nina's brilliant mind and caring heart. In 1996, I joined a busy litigation and tax controversy boutique in Baltimore, Maryland, after completing a U.S. Tax Court clerkship with Special Trial Judge Stanley Goldberg. From the early days of private practice, I was encouraged to take on pro bono tax matters from Maryland Volunteer Lawyers Service and to participate in the Internal Revenue Service (IRS) Volunteer Income Tax Assistance (VITA) program. ${ }^{2}$ As a young lawyer, these matters provided me with practical experience and the opportunity to interview clients; read and understand the notices, letters, and transcripts issued by the IRS; research myriad issues presented; and prepare strategies to resolve the problems. I am grateful to my firm and, in particular, the partner with whom I worked, Paula Junghans, for allowing me to take on these cases and to learn from these experiences. Moreover, it was through these cases and working with the tax clinic and the VITA program that I came to know Nina Olson. At that time,

\footnotetext{
${ }^{*}$ Partner, Kostelanetz \& Fink LLP.

${ }^{1}$ Nina Olson, The Tax Section's Role as an Advocate for Equal Access to Justice: A Personal History, 68 TAX LAW. 427, 427 (2015).

${ }^{2}$ Free Tax Return Preparation for Qualifying Taxpayers, INTERNAL REVENUE SERV., https://www .irs.gov/individuals/free-tax-return-preparation-for-qualifying-taxpayers (last visited Nov. 18, 2020).
}

Pitt Tax Review | ISSN 1932-1821 (print) 1932-1996 (online)

DOI 10.5195/taxreview.2020.118 | http://taxreview.law.pitt.edu 


\section{4 | Pittsburgh Tax Review |Vol. 182020}

she was building a reputation as a fierce advocate for low-income taxpayers in Richmond. ${ }^{3}$

Before the infamous congressional hearings in the spring of 1998 regarding alleged IRS abuses, ${ }^{4}$ we represented clients facing aggressive audit and collection actions without the benefit of due process rights or a single point of contact within the IRS to seek equitable relief. Following the very public airing of taxpayer complaints, Congress passed the IRS Restructuring and Reform Act of 1998 (RRA '98), ${ }^{5}$ a sweeping transformation of the IRS's structure, governance, and oversight. RRA '98 created the Office of the Taxpayer Advocate, local taxpayer advocate offices, and low-income taxpayer clinics. ${ }^{6}$ Congress also instituted processes and procedures to give taxpayers meaningful access to administrative appeals and judicial review of lien and levy actions, protection against repetitive audits, and expanded "innocent spouse" relief. ${ }^{7}$

For several years after the enactment of RRA '98, tax enforcement action declined as IRS personnel sought to avoid the impact of section $1203,{ }^{8}$ which provided a list of ten actions by IRS employees that result in termination. ${ }^{9}$ After a brief respite, enforcement efforts returned ${ }^{10}$ and the need for a strong National Taxpayer Advocate moved up in priority. In 2001, Nina stepped up to the plate and under the microscope.

${ }^{3}$ Olson, supra note 1 , at 428 .

${ }^{4}$ Senate Panel Hears Stories of Alleged IRS Abuses, CNN.COM (Apr. 28, 1998), https://www.cnn .com/ALLPOLITICS/1998/04/28/irs.hearings/.

${ }^{5}$ Internal Revenue Service Restructuring and Reform Act of 1998, Pub. L. No. 105-206, 112 Stat. 685 [hereinafter RRA '98].

${ }^{6}$ Id. $\S \S 1102,3601$.

${ }^{7}$ See id. $\S \S 3201-3202,3421-3468$ (expanding innocent spouse relief). On July 22, 1998, Congress repealed $\S 6013(\mathrm{e})(1)$ and enacted $\S 6015$ as part of RRA '98, $\S 3201(\mathrm{a}), 112$ Stat. at 734. The new relief provision was given retroactive effect with respect to any liability remaining unpaid as of July 22, 1998. RRA '98 $\S 3201(\mathrm{~g})(1), 112$ Stat. at 740. "It is clear that Congress intended section 6015 to be applied broadly and expansively to provide relief for joint and several tax liabilities remaining unpaid as of the effective date of section 6015." Hopkins v. Comm'r, 120 T.C. 451, 458-59 (2003). (2013).

${ }^{8}$ William Hoffman, 15 Years After RRA '98: Time to Re-restructure the IRS?, 140 TAX NOTES 647

${ }^{9}$ RRA '98 § 1203.

${ }^{10}$ Hoffman, supra note 8.

Pitt Tax Review | ISSN 1932-1821 (print) 1932-1996 (online)

DOI 10.5195/taxreview.2020.118 | $\underline{\text { http://taxreview.law.pitt.edu }}$ 
Like other young lawyers, I was fortunate to have wonderful mentors and role models working at other firms, within tax clinics, and for government agencies. Nina was among those role models and many of us came to know her through her speaking, writing, and advocacy. Nina also was a leader among female tax practitioners, proving that we had a place at the table and could make our voices heard.

Nina taught us to focus, spend the extra time to really understand the issues, and make sure that we were as prepared as anyone else in the room. She showed us how to fight the good fight and not take no for an answer. She demonstrated how to speak truth to power, to not give in or give up, and to remember that behind every legal issue is a taxpayer, a family, or a community that will benefit from our efforts.

While Nina's impact on low-income taxpayers is well known, she advocated on behalf of all taxpayers - young and old, rich and poor, domestic and international, individuals and entities. For example, Nina has always been an advocate for taxpayers living overseas. In her 2011 annual report to Congress, she sounded the alarm that taxpayer service overseas had become an "important sideline," standing behind the main responsibilities of IRS tax attachés, which included "partner relationships, exchange of information agreements with foreign governments, and support of IRS investigations and examinations." 11 When the IRS eliminated the last four tax attaché posts abroad, ${ }^{12}$ Nina advanced the cause of international taxpayers, pointing out that by removing the attachés and terminating the Electronic Tax Law Assistance Program, ${ }^{13}$ the IRS shut down the only free dialogue available to those living overseas.

Nina faced similar issues in late 2015, with the enactment of the Fixing America's Surface Transportation Act (FAST Act), ${ }^{14}$ under which the State Department is authorized to deny, revoke, or limit a passport if the IRS omitted)

${ }^{11} 1$ NAT'L TAXPAyer AdVOCATe, 2011 ANNUAl RePORT to CONGRESS, at 139 (2011) (citations

${ }^{12}$ Helen Burggraf, IRS “Failing” American Taxpayers Abroad, AMS. OvERSEAS (Jan. 11, 2016), https://americansoverseas.org/en/irs-failing-american-taxpayers-living-abroad/.

${ }^{13}$ I.R.S. News Release IR-16-097 (July 7, 2016), https://www.irs.gov/pub/irs-news/ir-16-097.pdf.

${ }^{14}$ Pub. L. No. 114-94, § 32101, 129 Stat. 1312, 1729-32 (2015) (codified at I.R.C. § 7345).

Pitt Tax Review | ISSN 1932-1821 (print) 1932-1996 (online) DOI 10.5195/taxreview.2020.118 | http://taxreview.law.pitt.edu 
certifies to the State Department that an individual has seriously delinquent tax debt. The passport provisions of the FAST Act raised numerous questions and serious concerns for U.S. taxpayers around the world, and Nina reacted swiftly. Even though the IRS advised that it would not implement these collection tools until 2018, Nina and her team quickly analyzed the law and began fielding questions from taxpayers and practitioners. Among the numerous concerns identified were the failure to provide adequate notice to the estimated 270,000 taxpayers subject to the FAST Act, ${ }^{15}$ the limited time to address the situation before adverse action was taken, and the restriction of certain administrative rights in response to these collection efforts. ${ }^{16}$ Before the IRS began its official rollout, Nina identified passport denials and revocations as one of the most serious problems in her 2017 Annual Report to Congress. ${ }^{17}$

Of course, Nina did not stop there. Shortly after the IRS issued guidance on passport certification in January $2018,{ }^{18}$ Nina issued nearly 800 Taxpayer Assistance Orders, directing the IRS not to certify those taxpayers identified as having seriously delinquent debt with open cases with the Taxpayer Advocate. ${ }^{19}$ She also hit the speaking circuit, joining panels across the country, accepting invitations for webinars and interviews, and testifying before Congress about the impact of the passport provisions on a taxpayer's statutory rights under the Taxpayer Bill of Rights and constitutional right of due process. ${ }^{20}$

15 NAT'L TAXPAYER AdVOCATE, 2017 ANNUAL REPORT TO CONGRESS, at 73 n.3 (2017) (“These numbers reflect the number of taxpayers who meet certification criteria and do not qualify for an exception as of October 2017. Small Business/Self Employed Division (SB/SE) response to TAS's information request (Oct. 18, 2017).”).

${ }^{16}$ Id. at $73-83$.

${ }^{17} \mathrm{Id}$.

${ }^{18}$ I.R.S. Notice 2018-1, 2018-3 I.R.B. 299.

${ }^{19}$ Kelly Phillips Erb, IRS Grants Temporary Relief for Some Taxpayers in Danger of Losing Passports, FORBES (Aug. 20, 2019, 3:44 PM), https://www.forbes.com/sites/kellyphillipserb/2019/08/20/ irs-grants-temporary-relief-for-some-taxpayers-in-danger-of-losing-passports/?sh=375a $797 f 7012$.

${ }^{20}$ NAT'L TAXPAYER ADVOCATE, supra note 15, at 77 n.19 (“Article 13 of the Universal Declaration of Human Rights states 'Everyone has the right to leave any country, including his own, and to return to his country.' United Nations, Universal Declaration of Human Rights, GA Res. 217A (III), UN Doc A/810 (1948).”).

Pitt Tax Review | ISSN 1932-1821 (print) 1932-1996 (online) DOI 10.5195/taxreview.2020.118 | http://taxreview.law.pitt.edu 
These efforts, coupled with the work of Nina's colleagues and practitioners around the country, led to a reprieve effective July 25, 2019, whereby all taxpayers with open TAS cases would be decertified, and all new TAS cases that fall within the scope of the FAST Act would be systemically decertified. ${ }^{21}$ Unfortunately, this decision was later reversed by the IRS, ${ }^{22}$ so the struggle continues.

Nina also served as an advocate for taxpayers participating in the IRS offshore voluntary disclosure programs, arguing that many individuals who entered the programs between 2009 and 2013, albeit wealthy and often welleducated, were benign actors with inadvertent violations. Such taxpayers were forced to pay exorbitant penalties simply because they came in early, before the IRS announced the reduced penalty programs. Nina noted in her 2014 Annual Report to Congress that this approach erodes "taxpayer rights, such as the rights to pay no more than the correct amount of tax, challenge the IRS's position and be heard, appeal an IRS decision in an independent forum, and to a fair and just tax system."23 Nina's efforts reminded the IRS that not all taxpayers who have an interest in foreign accounts act with the intent to willfully violate U.S. tax laws. This battle continues today, as the IRS pursues draconian civil penalties for failures to file international tax forms and Foreign Bank and Financial Account Reports (FBAR) far in excess of any tax loss to the United States.

Nina also served as the spokesperson for the numerous taxpayers who struggled to find the right office or the right person within the IRS to address a particular issue. Ten years ago, local IRS offices were closing due to budget and staffing issues and taxpayers waited for hours on nationwide toll-free

\footnotetext{
${ }^{21}$ See Erb, supra note 19 (describing TAS-13-0819-0014 (Aug. 14, 2019)).

${ }^{22}$ Update on Passport Certifications and Taxpayer Advocate Service, INTERNAL REVENUE SERV., https://www.irs.gov/newsroom/update-on-passport-certifications-and-taxpayer-advocate-service (last updated Sept. 24, 2020) ("Excluding cases from certification solely on the basis that the taxpayer is seeking assistance from TAS could allow a 'won't pay' taxpayer to circumvent the intent of the legislation to obtain or renew a passport. Following the review of relevant considerations regarding these procedures, the IRS has determined that a blanket, systemic exception for anyone with an open TAS case is overly broad and could undermine the effectiveness of the statute enacted by Congress in the FAST Act to collect a seriously delinquent tax debt."). omitted).

${ }^{23} 1$ NAT'L TAXPAyer AdVOCATe, 2014 ANNUAl Report To CONGReSS, at 80 (2014) (emphasis
}

Pitt Tax Review | ISSN 1932-1821 (print) 1932-1996 (online) DOI 10.5195/taxreview.2020.118 | http://taxreview.law.pitt.edu 
phone lines, only to have their calls dropped due to high call volume. ${ }^{24}$ The IRS needed resources, and taxpayers' rights to quality service were being compromised. Nina elevated the issue as a "Most Serious Problem" in 201425 and continued to advocate for clear paths for customer service throughout her tenure. These efforts culminated with the release of the "Taxpayer Roadmap" in November $2019,{ }^{26}$ which illustrates the complexity of our tax system using the various stages of a taxpayer's journey. The end result looks similar to a New York City subway map and clearly demonstrates the labyrinth taxpayers must navigate as they attempt to comply with the internal revenue laws.

Nina has left a strong legacy. In addition to her Annual Reports, ${ }^{27}$ which should be read by every tax professional and elected official, her speaking engagements, which are still presented to full houses around the country, and her blog posts, which have been saved for future reference by more than a few practitioners, Nina left an army of advocates committed to the recognition, preservation, and implementation of taxpayer rights.

It has been said that our legacy is built on many things, the most important of which are the people we hire and place in leadership positions. Nina recognized this and invested a tremendous amount of time selecting, training, and developing an entire generation within the Taxpayer Advocate Service. She empowered her case advocates to build relationships with practitioners, think outside the box, and identify and use all available tools to overcome obstacles. For the first time, we had the first and last name, direct phone number, and direct fax number of an advocate for our clients and issues. We had someone we could call and who would call us back at a scheduled date and time. We had someone who would not give up when the going got tough.

Nina made us believe we could make a difference, and then she gave us the team to make that happen. With Nina's case advocates, every tax

\footnotetext{
${ }^{24}$ See generally Cong. Budget OfF., TREnds in the Internal Revenue ServicE's Funding AND ENFORCEMENT (2020).

${ }^{25}$ NAT'L TAXPAYER ADVOCATE, supra note 23, at 3-25.

${ }^{26}$ NAT'L TAXPAYER ADVOCATE, The Taxpayer Roadmap 2019, https://taxpayeradvocate.irs.gov/ Media/Default/Media/2020-JRC/TAS_Roadmap_32x32_FINAL-2.pdf.

${ }^{27}$ National Taxpayer Advocate Reports to Congress and Research, INTERNAL REVENUE SERV., $\mathrm{https}$ ://www.irs.gov/advocate/reports-to-congress (last updated Oct. 22, 2020).
}

Pitt Tax Review | ISSN 1932-1821 (print) 1932-1996 (online) DOI 10.5195/taxreview.2020.118 | http://taxreview.law.pitt.edu 
practitioner felt like they had back up, somewhere to go when all else failed, and shelter from the storm. No greater gift can be given to young professionals than the gift of encouragement and accomplishment, and Nina made that a reality.

Practitioners in Baltimore, where I practiced for 20 years, directly benefited from Nina's efforts with the appointment of our Local Taxpayer Advocate, James (Jim) Leith. ${ }^{28}$ Jim managed an incredible caseload but would always find the time in his busy schedule to participate in the annual Lifecycle of a Tax Controversy. He assisted with materials, presented the sessions, and remained available for follow-up questions. Following Nina's lead, Jim was and continues to be a tireless champion for Maryland taxpayers and one of my personal tax heroes. That is Nina's legacy, in Maryland and throughout the country.

On a personal note, Nina is a dear friend and continues to be a close confidant. She is someone who always puts others first and sincerely cares how you are doing. She is quick to smile, to laugh, and to spark joy in those in her company. Nina has a large fan club for good reason and we are better for knowing her.

${ }^{28}$ See, e.g., Eileen Ambrose, Is Your Tax Preparer Changing Your Return to Collect a Refund?, BALT. SUN (July 15, 2012), https://www.baltimoresun.com/business/bs-bz-ambrose-preparer-20120715story.html (interviewing Jim Leith).

Pitt Tax Review | ISSN 1932-1821 (print) 1932-1996 (online) DOI 10.5195/taxreview.2020.118 | http://taxreview.law.pitt.edu 
